\title{
Economic Valuation of Mangrove Forest in Muara Village, Indonesia
}

\author{
I P Sari ${ }^{1 *}$ M P Patria ${ }^{1}$ \\ ${ }^{1}$ Biology Department, Faculty of Mathematics and Sciences, Universitas Indonesia, Jakarta, Indonesia \\ *Corresponding author. ininpuspita@gmail.com
}

\begin{abstract}
Mangrove forest is an essential part of the coast area in Muara Village, Teluknaga District, Tangerang City. Research of economic valuation in mangrove forest around Muara Village has been conducted. The aim of this research were to calculate and analyze the economic value of the advantage from mangrove forest ecosystem. Collecting the data was conducted with direct observation and interviews. The results of direct advantage economic value were obtained from direct information from local community. Direct value advantage of mangrove forest wereIDR9,200,375,000/year. Indirect advantages from ecosystem service of mangrove forest were IDR1,715,317,428,000/year. Existence value advantage was obtained with a value IDR $273,530,833 /$ year. The option value advantage of biodiversity value wereIDR 57,510,000/year. Total Economic Value (TEV) of mangrove forest in Muara Village wereIDR1,724,848,843,833/year.

Keywords: Ecosystem service, Mangrove forest, Teluknaga, Value economic.
\end{abstract}

\section{INTRODUCTION}

The acceleration of population and economic growth in society in line with the increasing needs of life such as infrastructure, agricultural land, plantations and other sectors. The increase in demand that occurs causes threats and pressures to damage the environment (ecosystem) and natural resources also getting higher6. Mangrove ecosystems as one of the potential natural resources that experience environmental degradation due to anthropogenic behavior. Converting land into residential areas and ponds in coastal areas is one of the causes of the degradation of mangrove ecosystems.

One of the mangrove ecosystem areas that are converted into seaweed farming fields, rice fields, and ponds is a mangrove ecosystem area in Teluknaga District, Tangerang City. Currently, mangrove ecosystem with an area of 500 ha decreasing every year due to land conservation. Degradation of mangrove forest has an impact on communities in the coast region due to the reduction in the source of clean water and settlements that are flooded every time the tide 8 . The mangrove ecosystem has a very comprehensive role and function covering physical functions 5 as a deterrent for abrasion, protection against wind and waves, storing carbon stocks 2 and producing nutrients3. Biological functions1 as spawning grounds and care for various biota, bird nesting sites and other marine biota habitats. In addition, mangroves have an economic function5 as a source of wood, fishery products, agriculture, fruit, raw materials for paper, leather and medicine. Therefore, seeing the importance of ecosystem functions and services from the presence of mangroves in the coastal area of Teluknaga District,
Tangerang City, economic valuation is needed to determine the value generated from the use of mangroves. The aims of economic valuation calculation are shown the economic valuation total as a reference in the utilization of mangrove ecosystems that are sustainable, it is an effort to conserve mangrove ecosystems and to create policy in natural resource management 10 . The assessment process is carried out by giving a price tag to the goods and services produced $9 ; 7$. The value of goods and services produced by mangroves is divided into two types, that is use value and non-use value. The use value includes the direct use value, the indirect use value and option value, while the non-use value is seen through the existence value4. The research is expected to provide information and knowledge to communities of the importance of mangrove forest conservation especially in the coastal areas of Teluknaga District, Tangerang City. It also provides consideration for the government to sustainably manage coastal areas.

\section{MATERIAL AND METHODS}

\subsection{Experiment Design}

The study was collected in May-July 2019 in Teluknaga District, Tangerang City (Figure 1). Collecting data was conducted through semi-structured interviews with key informants and respondents, observations, also literature studies. Key informants and respondents were decided by purposive sampling method11. Data collected in the form of economic value from the use of direct, indirect, option, and existence of mangroves. Data were analyzed quantitatively by explaining the economic value of 
mangroves and analyzed descriptively by describing the socio-economic activities of the people in the area.

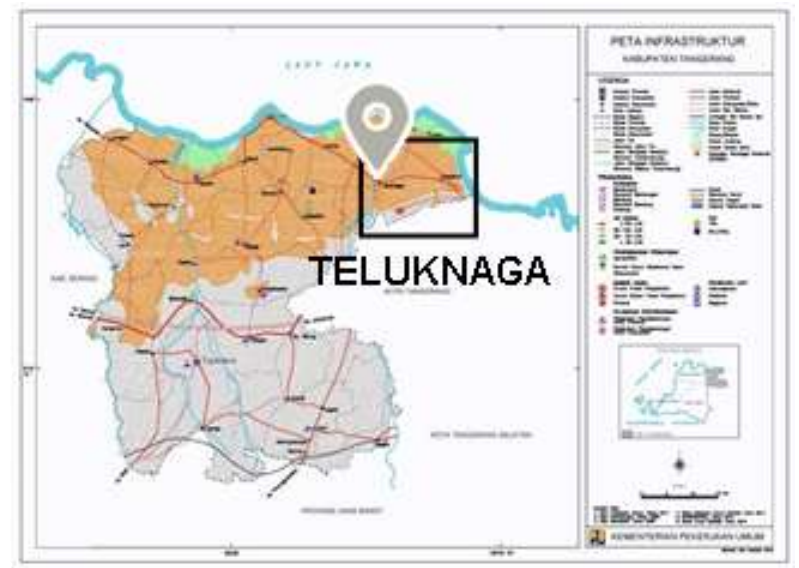

Figure 1. Study site in Muara Village, Teluknaga District

\section{RESULT AND DISCUSSION}

Administratively, Muara Village is in the north of Teluknaga District, Tangerang City and is directly adjacent to the Java Sea. Generally, the people have a livelihood as fishermen and fishers. The community of Muara Village lives around the mangrove forest area and relies on the mangrove ecosystem as one of the fulfilment of their daily needs. Mangroves in the Muara Village community play an important role in holding marine abrasion, habitat for marine biota, especially fish, shrimp and crabs, fish farming, and environmental services as a source of oxygen production. The mangrove forest area of Muara Village has an area of around 270 ha12; 13. An area of 21 ha is managed by the community and the rest is managed by Perhutani in West Java and Banten. The existence of very intensive human activities in the mangrove forest area will gradually have a major impact on the sustainability of the ecosystem. Observation results indicate the greatest use of ecotourism in mangrove and crab forests. Utilization is one of the direct benefits obtained by the community from the presence of mangrove ecosystems. These direct benefits can be assessed economically. Other economic values of indirect benefits, value of choice, and value of existence also need to be evaluated. It aims to increase knowledge as well as awareness for the community that mangrove ecosystems are not only useful and can be exploited directly but also have indirect value, namely as environmental services. The economic values of mangrove forests in Muara Village which have been evaluated as follows:

Direct Use Value

The value of direct benefits is the economic value obtained from the direct use of environmental resources by the community around the mangrove forest. The direct benefit value in Muara Village consists of eight sources of benefits, namely the use of mangrove seeds, ecotourism, fishes, crabs, small crabs, dry shrimps, fermented shrimps, and shrimps (Table 1).

Table 1. Direct Use Value

\begin{tabular}{|c|c|c|c|}
\hline No. & Resources & $\begin{array}{l}\text { Direct Use } \\
\text { (IDR/year) }\end{array}$ & $\begin{array}{c}\text { ValuePrecentage } \\
(\%)\end{array}$ \\
\hline 1. & Mangrove seed & $30,000,000$ & 0.33 \\
\hline 2. & Ecotourism & $3,960,000,000$ & 43.04 \\
\hline 3. & Fishes & $771,975,000$ & 8.39 \\
\hline 4. & Crabs & $511,000,000$ & 5.55 \\
\hline 5. & Small crabs & $2,430,900,000$ & 26.42 \\
\hline 6. & Dry shrimps & $182,500,000$ & 1.98 \\
\hline & \multicolumn{3}{|c|}{ Fermented shrimps } \\
\hline 7. & & $766,500,000$ & 8.33 \\
\hline$\underline{8}$. & $\underline{\text { Shrimps }}$ & $547,500,000$ & $\underline{5.95}$ \\
\hline
\end{tabular}

The highest economic value of mangroves in Muara Village is generated from the use of ecotourism in the amount of IDR 3,960,000,000/year. This value is obtained from the result of the multiplication of the price of the tourist ticket entry which is IDR. 8,250,000/week with the amount of utilization 480 times during the year. The high economic value of ecotourism shows great public interest in recreation. This is also supported by the mangrove forest area of Muara Village which borders directly with the Java Sea so that the community can at the same time relax on the beach. Mangrove forest ecotourism in Muara Village is a tourist attraction that is managed directly by the local community. This can improve the welfare of the local community as well as a business opportunity so that the community is indirectly involved in the preservation of mangrove forests for the long term. Another highest economic value from the use of mangroves is directly obtained from the small crab. The economic value generated is IDR $2,430,900,000$. This value is obtained from the crab market price of IDR. $83,250 / \mathrm{kg}$ multiplied by the amount of utilization reaching $29,200 / \mathrm{kg} /$ year. Despite the high utilization of crabs, but there is a conservation behavior carried out by local communities that is not taking individual crabs that are laying eggs. The community believes that the crab must be removed in order to reproduce again. The lowest economic value is the use of mangrove seedlings. That is because only mangrove forest area managers utilize mangrove seedlings for sale.

Indirect Use Value

The value of indirect benefits in the mangrove ecosystem of Muara Village is obtained through the services of environmental resources, namely as a barrier to abrasion, waves and tsunamis, as well as nursery ground, spawning ground and feeding ground. The indirect benefit value from abrasion barrier is to use replacement costs through estimating the cost of making break water. Based on the Ministry of Public Works 2018, the cost of making break 
water with a size of $50 \mathrm{~m} \times 1.5 \mathrm{~m} \times 2.5 \mathrm{~m}(\mathrm{p} \times 1 \times \mathrm{t})$ and endurance for 5 years is IDR $291,994,000$ or IDR $5,839,880 /$ meters. The length of the coastline in Muara Village is 3000 meters so that an economic value of IDR $17,519,640,000$ is produced for five years, equivalent to IDR 3,503,928,000/year. The value of other indirect benefits as nursery ground, spawning ground and feeding ground is obtained through the estimation of the catch of mangrove fishery products, reach IDR $1,711,813,500,000 /$ year. The total indirect use value obtained were IDR 1,715,317,428,000/year (Table 2).

Table 2. Indirect Use Value

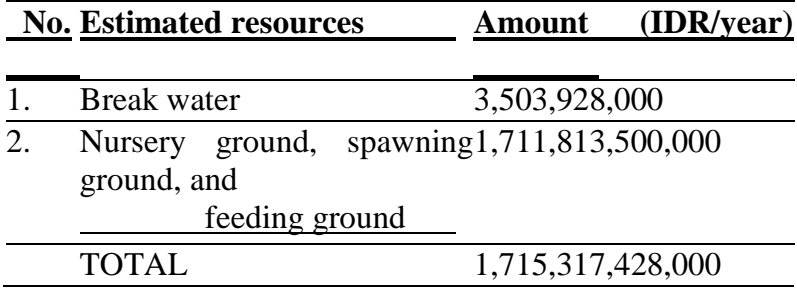

\section{Option Value}

The value of choice is obtained through the transfer benefit approach, namely by calculating the value of biodiversity in the mangrove ecosystem. The calculation refers to the biodiversity value of US\$ 15 ha/year14 multiplied by the total area of mangroves in an area. The result of multiplication of mangrove forest area of 270ha with biodiversity value is obtained by the economic value of the benefits of the choice of mangove in Muara Village in 2019 of US\$ 4,050/year or in rupiah equivalent to IDR $57,510,000 /$ year or IDR 213,000/ha/year. The economic value of choice in Muara Village is smaller when compared to the benefits of the choice of mangrove forests in MuaraGembong District, Bekasi of IDR 593,345/ha/ year4. This is influenced by differences in mangrove area in each region and the rupiah exchange rate.

Existence Value

The benefits of existence can be done through interviews and measured based on the willingness or contribution of individuals to pay (willingness to pay) as a form of concern for someone in maintaining and maintaining the quality and preservation of mangrove ecosystems. Based on the calculation of the value of the existence of the benefits of mangrove ecosystems in the Muara Village of IDR 273,530,833/year or IDR $6,078,463 / \mathrm{ha} /$ year.Willingnes to pay generated in each region varies depending on the willingness of the community to pay, the greater the costs incurred, the greater the community's awareness of the benefits derived from the existence of mangrove ecosystems. The value of the benefits of existence is influenced by the level of education, knowledge, and income of the community 15.

Total Economic Value (TEV)

Total Economic Value is the sum of the total value of direct use value, indirect use value, option value, and existence value. The total economic value generated by mangroves in Muara Village in 2019 reaches IDR $1,724,848,843,833$ /year (Table 3 ).

Table 3. Total Economic Value

\begin{tabular}{llll}
\hline \hline No. & Advantages & Amount (IDR/year) & $\begin{array}{l}\text { Precentage } \\
(\mathbf{\%})\end{array}$ \\
& & & \\
\hline \hline \multirow{2}{*}{ Direct Use Value } & & 0.53 \\
& & & \\
\hline 2 & $\begin{array}{l}\text { Indirect Use } \\
\text { Value }\end{array}$ & $1,715,317,428,000$ & 99.45 \\
\hline 3 & Option Value & $57,510,000$ & 0.00 \\
\hline 4 & Existence Value & $273,530,833$ & 0.02 \\
\hline & & & \\
\hline TEV & $1,724,848,843,833$ & 100 \\
\hline
\end{tabular}

Mangrove forests in MuaraTeluknaga Village have a greater economic value than other regions. For example, compared to TEV mangroves in MuaraGembongBekasi, only IDR 23,690,709,886/years4, in Merauke Regency which reached IDR. 213,344,656,759/years10,and in the Mahakam delta of IDR 503,071,398,86916. The difference in mangrove TEV in each region shows that mangroves are in good condition or not. Mangrove ecosystems with good conditions generally have a larger TEV. This is in line with the high availability of environmental resources in the mangrove ecosystem. This has an impact on increasing the economic benefits gained by the community.

Total economic value results also indicate that the highest economic value is at the value of indirect benefits. This indicates that environmental services play an important role in providing economic benefits. Indirect benefits that can be recommended other than as abrasion and wave protection as well as nursery ground, spawning ground, and feeding ground are carbon potential. Carbon storage and sequestration is known to contribute the greatest economic value compared to other indirect benefits 17.The value of benefits is not directly in line with mangrove ecosystem management. Sustainable management of mangrove forests will have a positive impact on the sustainability of indirect benefits in the future. 


\section{CONCLUSION}

The results of direct value advantage in mangrove forest were IDR 9,200,375,000/year. Indirect advantages from ecosystem service of mangrove forest were IDR $1,715,317,428,000 /$ year. Existence value advantage was obtained with a value IDR 273,530,833/year. The option value advantage of biodiversity value were IDR 57,510,000/year. Total Economic Value (TEV) of mangrove forest in Muara Village were IDR $1,724,848,843,833 /$ year.

\section{REFERENCES}

[1] Aksornkoae S 1993 Ecology and management of mangroves. IUCN Wetlands Programme, Bangkok

[2] Dharmawan IWS \& CA Siregar 2008 KarbontanahdanpendugaankarbontegakanAvicen nia marina (Forsk.) Vierh.diDesaCiasem, Purwakarta. Penelitianhutandankonservasialam 4:317-328

[3] Husain SA \&Badola R 2008 Valuing mangrove ecosystem services: Linking nutrient retention function of mangrove forest to enhanced agroecosystem production. Wetland Ecology Management 16(6):441-450

[4] Muntalif BS, Hasian O \&Sembiring E 2013 Valuasiekonomidanupayapengelolaanhutan mangrove

KecamatanMuaraGembongKabupatenBekasi. JurnalTeknikLingkungaan 19(1):82-90

[5] Prasetiyo DE 2013 Strukturkomunitas mangrove dankepiting (OcypodidaedanGrapsidae), sertapendugaankarbontersimpanpadakomunitas mangrove di Kabupaten Raja Ampat. SkripsiUniversitasJendralSoedirman, Purwokerto

[6] Prasetiyo DE, Zulfikar F, Shinta\&Zulkarnain I 2016 Valuasiekonomihutan mangrove di PulauUntungJawaKepulauanSeribu:

Studikonservasiberbasis green economy. OmniAkuatika 12(1):48-54

[7] Pratama A, Agustriani F \&Nurhadi 2017 Valuasiekonomisumberdaya mangrove studikasus di SPTN I dan SPTN II Taman NasionalSembilangKabupatenBanyuasin,

Provinsi Sumatera Selatan. MaspariJournal 9(2):111-120

[8] Sungkawa, QT 2015 Pengembanganpotensihutan mangrove untuktujuanekowisata di DesaMuaraKecamatanTeluknaga,

KabupatenTangerang. Skripsi Program StudiManajemenHutan, FakultasKehutanan, InstitutPertanian Bogor, Bogor: 25 hlm.
[9] Tuwo,

A

2011

Pengelolaanekowisatapesisirdanlaut

(pendekatanekologi, sosial-ekonomi,

kelembagaan, dansaranawilayah). Sidoarja: BrilianInternasional.

[10] Widiastuti, MMD, Ruata NN \&Arifin T 2016 Valuasiekonomiekosistem mangrove di wilayahpesisirKabupatenMerauke. JurnalSosek KP 11(2):147-159

[11] Sheil, D, Puri RK, Basuki I, van Heist M, Wan M, Liswanti N, Rukmiyati, Sardjono MA, Samsoedin I, Sidiyasa K, Chrisandini, Permana E, Angi EM, Gatzweiler F, Johnson B \&Widjaya A 2004 Mengeskplorasikeanekaragamanhayati, lingkungan,

danpandanganmasyarakatlokalmengenaiberbagai lanskaphutan. Metodemetodepenilaianlanskapsecaramultidisipliner.

CIFOR, Bogor:ix+101

[12] BadanPerencanaandan Pembangunan Daerah $2013 \quad$ ProfildaerahKabupatenTangerang. Bappeda, Tangerang.

[13] Aini HN, Rusdiana O \&Mulatsih S 2015 Identifikasitingkatkerawanandegradasikawasanh utan mangrove DesaMuara, Tangerang, Banten JurnalPengelolaanSumberdayaAlamdanLingkun gan 5(1):79-86

[14] Ruitenbeek HJ 1992 Mangrove management: An economic analysis of management options with a focus on Bintuni Bay, Irian Jaya. Jakarta.

[15] Indriyanti MD, FahrudinA\&Setiobudiandi I 2015 Penilaianjasaekosistem mangrove di TelukBlanakan, KabupatenSubang. JurnalIlmuPertanian Indonesia 20(2):91-96

[16] Wahyuni Y, Putri EIK \&Simanjuntak SMH 2014 Valuasi total ekonomihutan mangrove di kawasan Delta Mahakam, KabupatenKutaiKartanegara, Kalimantan Timur. JurnalPenelitianKehutananWallacea 3(1):1-12

[17] Rosadi SD 2018 Potensikarbondanvaluasiekonomi mangrove di Kecamatan Gerung, Kabupaten Lombok Barat. TesisFakultasMatematikadanIlmuPengetahuanAl am, Program StudiPascasarjanaBiologi. Depok: $\mathrm{i}+75$. 